\title{
Il braccio violento della legge: Revelation, conspiracy and the politics of violence in the poliziottesco
}

\section{ABSTRACT}

This article analyses a strand of the Italian police thriller (poliziottesco) whose plots invest heavily in notions of official cover-up and high-level coup d'état conspiracy, in the cultural, political and historical coordinates of the 'anni di piombo'/'years of lead'. Prevailing scholarly discourses on the cinema of and about this era tend to identify a desire to seek explanation for the violent traumas and to see through the opaque webs of intrigue that characterize the national memory of the 1970s. By taking La polizia ringrazia/Execution Squad (Steno, 1972), Milano trema la polizia vuole giustizia/Violent Professionals (Martino, 1973) and La polizia accusa: il servizio segreto uccide/Silent Action (Martino, 1975) as key examples, this article seeks to demonstrate that such films in fact occupy a divergent register of political address: one that seeks, not to explain or 'make sense' of the era's intrigues, but instead to enact a ritual recognition of innate suspicion, pervasive corruption and assumed distrust. These films are appraised for their immediacy rather than their coherence, as documents of confusion rather than of investigative rigour. They thus enable a reading of 'political cinema' as being one that chronicles the range of political registers through which events were being represented to sections of the Italian public.

\section{KEYWORDS}

poliziottesco poliziotteschi popular cinema political cinema history and cinema years of lead transatlantic 
1. I use the word 'poliziottesco', not in its originally pejorative sense (suggesting trashy ephemera), but instead to highlight the modes of production and consumption that characterized the 1960s/1970s 'filone' milieu: rapid production schedules and concerted exploitation of markets, as opposed to the more celebrated and contemporaneous political 'auteur' films of (among others) Francesco Rosi, Gillo Pontecorvo or Elio Petri.

2. For example, the wide-ranging and fan-maintained 'Grindhouse Cinema Database' (which aspires to be "the ULTIMATE online classic Exploitation film wiki/database') lists 103 films under the poliziottesco umbrella, including police procedural, mafia, vigilante, heist and gangster films, as well as giallo crossovers, but leaving out La polizia ringrazia/Execution Squad (Steno, 1972). This is testament to the innate nebulousness and hybridity of filone categories in this era of Italian cinema.

3. My focus in this article is not on the large sub-set of mafia films (such as Fernando Di Leo's Milano calibro 9/Calibre g (1972), La mala ordina/The Italian Connection (1972) and Il boss/The Boss (1973)), which also posit official corruption or judicial weakness. Many if not all poliziottesch assert some degree of governmental incompetence or wrongdoing I am instead concerned here with films that explicitly depict official collusion in
Scholarship on Italian cinema's negotiation with the anni di piombo tends to situate such film-making as the manifestation of a collective desire: a desire to seek explanation for the traumas, to offer a semblance of coherence where confusion reigns, and to see through the opaque webs of intrigue that characterize the national memory of the 1970s. Certainly, the fascination with the period in the nation's cinematic output to this day attests to the events' on-going capacity to confound comprehension and to inspire historical investigation. Films produced during the period itself, however, show us that such an approach was just one available register for the interpretation and mediation of Italy's political surroundings. Through the analysis of a group of films that are commonly categorized within the poliziottesco filone, ${ }^{1}$ this article investigates a divergent register: that which offered audiences spectacular acts of unmasking and emotional release rather than narrative coherence or sophisticated examination of socio-political processes. My aim is to assess these films' significance for the study of both Italian cultural history and the politics of popular film-making more broadly, and thus to offer an alternative perspective on cinema's role in Italy's decennio maledetto.

Depending on one's definitions, around 100 poliziotteschi were produced between the late 1960s and the early 1980s. Though the label is usually understood to describe a 'police procedural' generic paradigm, it is also frequently applied to mafia, vigilante or heist narratives. ${ }^{2}$ This study is not therefore a 'genre survey'; nor do I seek here to provide a wide-ranging, industry-based production history to account for the proliferation of such an expansive 'crime' filone. Rather, my focus is on a subset of these films, whose plots revolve around the exposure of official cover-ups and high-level coup d'état conspiracies. ${ }^{3}$ La polizia ringrazia/Execution Squad (Steno, 1972), Milano trema - la polizia vuole giustizia/Violent Professionals (Martino, 1973), La polizia sta a guardare/The Great Kidnapping (Infascelli, 1973), La polizia accusa: il servizio segreto uccidel Silent Action (Martino, 1975), Poliziotti violenti/Crimebusters (Tarantini, 1976) and Il grande racket/The Big Racket (Castellari, 1976) offer particularly striking examples of this tendency, each ostensibly providing a revelatory denouement concerning official culpability or authoritarian conspiracy. Yet such a reading overlooks an important point about political discourse in this era: namely, that such assertions of institutional corruption were not necessarily revelatory to an Italian public whose cognizance of political intrigue was incomplete, but growing. Building upon astute recent work by O'Leary on the poliziottesco's ritual function (2011) and Marlow-Mann on the centrality of emotion in this filone's operation (2013), I seek to examine the epistemological status of this 'conspiracy' subset within these cultural, historical and political contexts.

This strand of the poliziottesco must firstly be located within a confluence of political and cinematic factors at the start of the 1970s. The ferments that followed the bombing of Milan's Piazza Fontana in December 1969, intensified with the official cover-up that surrounded the atrocity's neo-fascist culpability, and continued throughout the decade to follow, are well documented. The Italian Ministry of the Interior's bare statistics record 14,591 'politically motivated' acts of violence on people or property between 1969 and 1987, resulting in 491 deaths and 1181 injuries (Cento Bull and Cooke 2013: 13). Equally well studied is the fact that, beneath these figures, the acts of violence were diverse in their nature, their motivation and in the ways in which they have been represented through cinema (see, e.g., O'Leary 2011: 79-83). Clandestine militant groups on the political left, most famously the Brigate Rosse, broadly emerged from extremist wings of the era of mass protest at the
1.

2.

3.

4.

5.

6.

7.

8.

9.

10.

11.

12.

13.

14.

15.

16.

17.

18.

19.

20.

21.

22.

23.

24.

25.

26.

27.

28.

29.

30.

31.

32.

33.

34.

35.

36.

37.

38.

39.

40.

41.

42.

43.

44.

45.

46.

47.

48.

49.

50.

51.

52. 
end of the 1960s in perceived defence against a rising neo-fascism, and graduated through sabotage and kidnappings to targeted political killings (most notoriously of former Prime Minister Aldo Moro in 1978). Clandestine groups on the political right, such as Ordine Nuovo and Avanguardia Nazionale, instigated the indiscriminate bombing campaign known as stragismo (or 'massacre-ism'), and operated on a considerably more covert level.

The films that provide this article with its chief subject matter address the latter form of political violence, and specifically the intrigues that surrounded it when evidence began to surface that sections of the secret services and other state institutions were supporting the attacks in an effort to spread fear and promote authoritarian coup d'état (a strategy that became known as the strategia della tensione). On the most obvious and direct levels, these tales of rogue cops in contemporary urban Italian locales, who both fight violent crime and unmask the neo-fascist power structures lurking behind it, operate as popcultural representations of, and responses to, these events. This said, both leftand right-wing forms of violence informed the broader discursive construction of an Italy spiralling out of control. Both therefore provide important contexts for this study of cultural and ideological processes of representation, as does the prominent position of these years' emblematic events in the Italian media and, by extension, the popular imagination. The films under scrutiny here predate the moment of greatest tension that followed the Moro kidnapping and heralded the formulation of the 'anni di piombo' (literally, 'years of lead') as a traumatic and contested period of Italian history, which has ever since had a lasting impact on the country's political and cultural memories. This article will therefore examine these films as documents of a formative period in this larger discourse of national trauma.

While such local specificity provides the contextual fulcrum of this study, it is also important to take account of the globally oriented aspects of this cultural moment. Such a 'translocal' approach as has been advanced in the pages of this very journal serves to emphasize the nomadic and outward looking, rather than strictly 'nationally' constituted, nature of Italian identities (see Laviosa 2013: 4). Accordingly, many poliziotteschi interweave their local political backdrops with cinematic and cultural contexts that register the international influence and reach of American cinema. The 'police procedural' paradigm possessed a rich heritage, not in Italy, but in Hollywood. Yet it provided an apt generic model for Italians through which to negotiate neuroses surrounding the individual's relationship to institutional justice and societal power structures. From G-Men (Keighley, 1935) onwards, through Where the Sidewalk Ends (Preminger, 1950) and On Dangerous Ground (Ray, 1952), to Bullitt (Yates, 1968), the American cop film repeatedly brings into question the legitimacy of codified law and state power, negotiating a constant tension around the 'social contract' whereby citizens relinquish freedoms to centralized mechanisms of law and order. As Tomas Leitch explains, the figure of the 'rogue' law-enforcer who is compelled to break the law in order to uphold an alternative moral code in defiance of 'the system that has failed them and the society they are sworn to protect' was by the 1960s an archetype of Hollywood social commentary (2002: 229).

It is easy to see how such an ideologically charged generic model as this could be transposed to the machinations of 1970s Italy, and little surprise that its latest manifestations might find a receptive audience there. As Christopher Barry has outlined (2004: 78-82), the poliziottesco's proliferation in the early to mid 1970s, while clearly a response to the local events of the anni di piombo,

\author{
acts of politically \\ motivated violence, \\ and that use this to \\ put forward theories \\ of authoritarian coup \\ plots.
}


4. See, for example, Wagstaff (1992) is also indebted to the arrival on the Italian market of internationally successful Hollywood cop thrillers such as Dirty Harry (Siegel, 1971) and The French Connection (Friedkin, 1971), as well as related crime or vigilante films (most notably Death Wish (Winner, 1974)). These products of Nixon-era neuroses over social breakdown and urban violence in the United States, with their depictions of maverick crime-fighters refusing to play by the rules, were significant box office hits in Italy, and their narrative, thematic and ideological tropes were replicated to cash in on a successful formula. As has been studied at length elsewhere (most commonly in relation to the poliziottesco's industrial forebear, the spaghetti western) ${ }^{4}$ this was a characteristic pattern of popular Italian cinema in the 1960s and 1970s. Such cycles would burgeon in an incremental balance between repetition and innovation, with an eye firmly trained on the perceived whims of the popular market and responsive to Hollywood's output.

It would be an oversimplification to say that Italian police procedurals were merely responding to Dirty Harry and its ilk. Execution Squad - commonly seen as a 'founding text' of the Italian format - was released two months prior to the arrival of Don Siegel's film on the Italian market. Nevertheless, the Italian releases of The French Connection in January 1972 followed by Dirty Harry in April of that year did have a notable impact upon both the cycle's recurrent plot devices and its ideological outlook, with film-makers selectively adopting narrative schemas from these Hollywood blockbusters, and localizing them. The marketing strategies that accompanied the American films in Italian cinemas markedly emphasized their apparent endorsement of draconian law enforcement techniques. The French Connection became 'Il braccio violento della legge'/'the violent arm of the law', while Dirty Harry's Italian release (as Ispettore Callaghan: il caso Scorpio è tuo) was accompanied by the sensational tag line ‘Non risolve i casi di omicidio... li annienta!' (He doesn't solve murder cases... he annihilates them!). Certain poliziotteschi, notably Violent Professionals, transposed such attitudes towards crime fighting from the American milieu into contemporary Italian locales. Martino's film depicts a rogue cop using violent methods of law enforcement in defiance of an ineffectual legal system, which is failing in its duty to uphold the rule of law. Only the hero's uncompromising methods are proved to work until, disgusted with the system he has defended, he discards his police-issue revolver in a clear nod to the final sequence of Dirty Harry (and by extension that of High Noon (Zinnemann, 1952)). In other words, Violent Professionals closely reproduces the ideological tropes of this Hollywood blockbuster, and shares Don Siegel's inheritance from the western genre: the lone hero cleaning up a community threatened by lawlessness and savagery; an innate distrust of the institutions of state; and an unambiguous assertion of the righteousness of lethal force in defiance of codified legality.

By no means, however, was this simply a case of imitation or emulation of transatlantic formats to indulge in fantasy narratives of tough law enforcers. Certainly, imported models from US cinema were an important driver behind this filone's development but, as Roberto Curti has written, the attitude to the state to be found in the poliziottesco is a key element that allows it to distinguish itself from the Hollywood format (2006: 96). In the poliziotteschi considered in this article, legal and governmental institutions are not weak and toothless, as they are in Dirty Harry; instead, they are all-powerful and actively malicious, pertaining to a widespread unease in Italian society over the culpability for the events of the anni di piombo. A persistent opacity
1.

2.

3.

4.

5.

6.

7.

8.

9.

10.

11.

12.

13.

14.

15.

16.

17.

18.

19.

20.

21.

22.

23.

24.

25.

26.

27.

28.

29.

30.

31.

32.

33.

34.

35.

36.

37.

38.

39.

40.

41.

42.

43.

44.

45.

46.

47.

48.

49.

50.

51.

52. 
surrounding the instruments of state fed strong (and justified) suspicions that the secret service was either aiding atrocities or covering up their culpabilities. It is indeed with this accusation that Violent Professionals most conspicuously diverges from the Dirty Harry model, the 'twist' ending coming as the chief of police reveals himself to be the hidden crime boss, manipulating the violence as part of an authoritarian strategia della tensione. Such investment in notions of high-level conspiracy is a recurrent feature within the poliziottesco, with the lone hero similarly unmasking conspiratorial coup plots of retired police chiefs (Execution Squad, The Great Kidnapping) lawyers (Crimebusters, The Big Racket) and members of the secret service (Silent Action).

Such a transatlantic cultural context therefore exists through and within these films' decidedly local focus, serving to illustrate the global constitution of Italian identities in this era. Through their negotiation with US genre convention, these films can be seen in a number of ways as documents of their locale and era. First, by turning to a signifier of American popular culture as a conduit for local political oppositions, they register an Italy in which such reference points were increasingly familiar. Furthermore, due to their tendency to utilize such tropes as the 'twist' ending to lay bare notions of state complicity, they have been discussed as films that seek to attach coherent, understandable narratives to an era of extreme cultural-political uncertainty. Peter Bondanella, for example, aligns the poliziottesco's social concerns with those of Italy's famed political auteurs such as Francesco Rosi, Gillo Pontecorvo, Elio Petri and Marco Bellocchio (2009: 453). The appeal of these film-makers' 1970 s conspiracy thrillers is identified by Mary P. Wood as lying in their 'attempt to impose order on a world which is perceived as difficult to understand, complex, mysterious, controlled by people who mask their control behind commonsense assumptions, coercion, and ritual' (2003: 153). Wood also places the poliziottesco within this spectrum of cultural output that 'attempts to establish the causes and attribute blame. Cinematic narratives of police investigations were [...] part of this impetus to give concrete form to fears and anxieties, and to understand what was happening in society' (2012: 29).

Christian Uva also identifies in the poliziottesco a desire to understand or to make sense of the era's intrigues, positioning this filone within a broader cultural trajectory in which cinematic images shaped popular perception of the events of the 1970s, to the extent that the divides between cinema and reality were at times imperceptible. Uva uses the opening sequence of Sbatti il mostro in prima pagina/Slap the Monster on Page One (Bellocchio, 1972) - a film depicting a fictional right-wing newspaper, which manipulates the events of the era to scapegoat the Left - as an emblematic example of this trajectory, in which 'reality enters cinema and cinema enters reality in an osmotic exchange, in which the boundaries of each seem to vanish' (Uva 2007: 9). ${ }^{5}$ Bellocchio's film begins with archive footage of the 1972 funeral of militant communist activist Giangiacomo Feltrinelli in Milan, and then seamlessly progresses into a dramatized representation of the street battles that were taking place around such events. Uva's argument raises pertinent questions over the ontological status of archive footage, and thus advances a wider methodology that interrogates archival manipulation as a strategy of mediating and defining this period's memory (see, e.g., Catherine O'Rawe's work on recent films such as Pasolini: un delitto italiano/Who Killed Pasolini? (Giordana, 1995) and La prima linea/The Front Line (De Maria, 2009), which posits their incorporation of archive footage as 'a determination to make visible the events of the past' (2011: 110),
5. All translations from the original Italian are mine. 
emphasizing how the 1970s remains a pivotal moment in the on-going negotiation of Italian cultural identities).

The diverse and important studies on the cinema of and about the anni di piombo outlined above therefore offer valuable insights into how the period has served as a locus for a search for meaning within a range of cinematic and political registers up to the present day. Uva situates the poliziottesco within these larger discourses, and frames it as a reflection of the popular imaginary and a way of processing and understanding the 'realities' of the era's complex events. The poliziottesco, he argues, functions as 'cinema understood as a reflection, but also as an elaboration, of a mass imaginary that changes with modifications in the socio-political reality from which it emerges' (Uva and Picchi 2006: 63). In this article, however, I will suggest an alternative perspective for analysing the poliziottesco's 'conspiracy' subset. These films pose problems for notions of cinema offering explanation or coherence, or providing a filter for 'reality': a point that becomes clearer when we consider the complexities of the relationship between acts of physical violence and their modes of representation in this cultural-political moment.

The violent events of Italy's 1970s were from the moment of their occurrence sites of profoundly contested political memory across numerous strata of cultural and political discourse. For example, the passage taken by certain leftist protest factions from the mass mobilization of the late 1960s to the clandestinity of armed struggle is a notoriously contentious topic. Sidney Tarrow argues that, from the moment the bomb in Piazza Fontana exploded on 12 December 1969, 'death and violence became contested symbolic terrain around which the political class reconstituted its unity and over which various elements of the extraparliamentary left competed for supremacy' (1991: 43-44). Political activists, state institutions and the mainstream press were immediately competing to confer their own meanings to both the act itself and the events that followed (such as the suspicious death in custody of suspect and anarchist Giuseppe Pinelli). While the Corriere della sera and the police laid the blame for the bombing on leftist anarchists, the militant journal Lotta Continua mobilized to expose neo-fascist culpability and a secret service cover up. Tarrow's analysis of the months that followed depicts a 'spiral of competitive tactical innovation' (1991: 43), whereby clandestine groups competed with each other to make not only their methods of activism, but also the significance they attached to those methods prominent in the popular consciousness.

This imperative amongst left-wing militant groups to 'be noticed' in this era also informs the analysis of David Moss, who examines the strategies necessary for them to 'disambiguate the otherwise politically meaningless language of violence' (1989: 8), by using a variety of cultural registers: videos, leaflets and banners, as well as longer political tracts or treatises. Lotta Continua, for example, attracted a broad readership by investing in overtly sensationalized reportage, in competition for attention with other revolutionary leftist outlets. Much scholarship has also focused on the decisions made by armed factions such as the Brigate Rosse, Potere Operaio and Prima Linea to undertake newsworthy forms of activism (such as bank robberies and kidnappings), to maximize the dissemination of the political meanings they ascribed to their own activities. Donatella Della Porta, for example, writes that between 1970 and 1983, 783 acts of violence were justified by their perpetrators as propagandist activities aimed at gaining support, while 263 were for purposes of self-defence and 219 were intended as acts of 'anti-repression' (assaults on
1.

2.

3.

4.

5.

6.

7.

8.

9.

10.

11.

12.

13.

14.

15.

16.

17.

18.

19.

20.

21.

22.

23.

24.

25.

26.

27.

28.

29.

30.

31.

32.

33.

34.

35.

36.

37.

38.

39.

40.

41.

42.

43.

44.

45.

46.

47.

48.

49.

50.

51.

52. 
the police or judiciary) (1995: 120). Well over half were therefore aimed solely at communicating the validity and efficacy of violent methods.

Even such a partial summary of the emergence and development of politicized violence in this era as is provided above makes two important things clear. First, rather than viewing films as filtering or reflecting interpretations or realities of the period, we must recognize that the very processes of mediation that grew around the events were inseparable from, and entwined within, those events themselves. The act of interpreting violence perpetrated by both the Left and the Right was an organic and active agent - indeed, a fraught cognitive battleground - in the developing discourse of 1970s 'terrorism'. Second, these processes of mediation manifested themselves in a wide variety of cultural and political registers. The investment in this cultural moment to be found within the poliziottesco's conspiracy mode is accordingly more complex than an attempt to explain or impose order on the material conditions that surrounded the films. This transatlantic exchange comprises recourse to Hollywood reference points, not as routes towards 'making sense' of the world, but instead as sites of ritual, spectacle and emotional release.

\section{'REVELATION' IN THE POLIZIOTTESCO}

To explore this argument, I shall begin where many critiques of the poliziottesco begin: with Execution Squad (1972). On the surface, Steno's film adheres to a straightforward detective/mystery narrative structure whereby key plot information is withheld from, and then incrementally revealed to, the audience: akin to the model famously identified by Bordwell and Thompson as depending 'on our curiosity - on our desire to know [...] what forces lurk behind certain events' (2010: 83). The film's protagonist, Commissario Bertone, embarks on a pursuit of armed robbers, but his efforts are frustrated by media and bureaucratic mechanisms that seem to favour the criminals. Bertone is then provided with a succession of hints that a clandestine right-wing organization is using the violence to influence public opinion and to take control until, finally, it is revealed that a cabal of politicians, industrialists, bankers and the former police commissioner (who has acted as Bertone's mentor throughout the film) is seeking to overthrow the state and instigate a dictatorship. Similar 'twist' endings, unmasking high-level neo-fascist coup d'état plots and thus making reference to the cover-ups surrounding the strategia della tensione, are also to be found in Violent Professionals (1973), The Great Kidnapping (1973), Silent Action (1975), Crimebusters (1976) and The Big Racket (1976). The clear concordances between such plots and the real-life intrigue of 1970s Italy cause Christopher Barry to identify 'accurate coverage' of this political backdrop, offering 'oppressed citizens an opportunity to see on the screen what newspapers at that time did not dare show' $(2004: 85,82)$.

The extent to which such a plot device can be taken at face value, by seeing it as providing a truthful revelation regarding the films' political surroundings, is however doubtful. Diegetically, it is true, an audience is aligned with Bertone, and hears of the intrigue lying behind the events incrementally as the protagonist articulates his gradual awakening (e.g., when he responds to the scene of a summary execution on the banks of the River Tiber with the observation that the crime has the 'puzza molto di fanatismo'/'a distinct smell of fanaticism', and in his next scene posits a theory that a radical group is seeking to undermine Italian democracy). This is not, however, to say that an audience is necessarily aligned with Bertone on an epistemological level, 
6. It is not universally the case that this imperative for rapid profit was focused on local audiences, since a high proportion of filone products were international co-productions and therefore in part designed for export markets. The logic of my claim here should not therefore be assumed. In the case of the poliziottesco, however, the vast majority of these films (including Violent Professionals, Silent Action, The Big Racket and Crimebusters) were made solely by Italian production companies. This production milieu was therefore one with a particular focus on domestic profits. or that it undergoes an equivalent realization. Alex Marlow-Mann takes a considerably more nuanced approach than accounts that offer literal readings of the political content of poliziotteschi, arguing instead that the ideological messages of such films are less important than the emotional investment or catharsis on offer to the viewer. Using The Big Racket as a case study, MarlowMann applies the ideas of moral philosopher Robert Solomon to illustrate how emotional responses are integral to processes of supposedly 'rational' cognition. Further, he argues that in the poliziottesco, whose raison d'être is the triggering of such emotional responses, 'the viewer must be consciously aware of the sociological and political tensions the filmmaker mobilizes and engage with them in order to respond fully on an emotional level' (2013: 140). In other words, rather than being passively granted the 'opportunity to see' hidden political depths, as Barry claims, specific audiences bring specific levels of prior knowledge into the viewing experience. Moreover, particularly given the imperative for rapid profit that characterized the Italian filone model, this suggests that film-makers would seek to work within the level of prior knowledge assumed to be shared by their immediate target market. ${ }^{6}$

This point becomes clearer, and conceptions of these films offering political revelation more problematic, when we further place the poliziottesco within the cultural-political framework of 1970s Italy. Despite sustained cover-ups, information about attempts at subversion and state-sponsored terror was in the public domain. The foiled coup orchestrated by General De Lorenzo in 1964, for example, had been made public by L'Espresso journalists in May 1967. As already mentioned, far-right culpability for the Piazza Fontana bomb, along with the cover-up orchestrated by the secret service, was exposed by investigative journalists affiliated with Lotta Continua, whose book La strage di stato (Anon 1970) sold over 100,000 copies between 1970 and 1972 (Lumley 1990: 123). Another abortive coup, led by the head of the neo-fascist party Fronte Nazionale, Prince Valerio Borghese, and supported by sections of the armed forces, was then made public in March 1971. Such instances of far-right violence, official cover-ups and suspicious judicial acquittals would continue throughout the decade, entering into the public consciousness to varying degrees (e.g., the bombing at Peteano in 1972, and the investigation into the Rosa dei Venti group's covert activities in 1974, which led to the arrest of the secret service head, Vito Miceli). Anna Cento Bull (2007) offers a comprehensive analysis of both contemporaneous and subsequent investigations into these events, detailing what was and what was not known at the time. The involvement of the CIA and NATO, for example, as well as the existence and links to right-wing terrorist organizations of the Masonic lodge P2 (whose membership comprised senior politicians and police officers, along with heads of the army, navy, air force, judiciary and secret service) would remain hidden until the 1980s. The picture that emerges is therefore one, not of certainty or clarity, but one of hearsay, innuendo, diffuse unease and inchoate suspicion that subversive intrigue was afoot within the Italian state (Cento Bull 2007: 59). While it is true that the full extent of state culpability has never been revealed, therefore, one thing is apparent. The notion that senior officials from the secret services, the army, the police force and the judiciary might be conspiring to topple the liberal-democratic status quo and curtail a perceived communist encroachment by sponsoring neo-fascist violence, though not yet understood in a concrete sense, was a plausible and accessible outlook in Italy by the mid 1970s.

The films that comprise my chief focus were released on the Italian market between 1972 and 1976 and, through their recourse to ostensibly revelatory
1.

2.

3.

4.

5.

6.

7.

8.

9.

10.

11.

12.

13.

14.

15.

16.

17.

18.

19.

20.

21.

22.

23.

24.

25.

26.

27.

28.

29.

30.

31.

32.

33.

34.

35.

36.

37.

38.

39.

40.

41.

42.

43.

44.

45.

46.

47.

48.

49.

50.

51.

52. 
denouements, provide documents of this period's confusions. They simultaneously register the assumption of a corrupt state and the incompleteness of concrete knowledge about this corruption, through their simplified depictions of conspiracy. Each film adopts a 'detective' narrative structure similar to that outlined above in the case of Execution Squad, and each similarly presents a protagonist who undergoes a realization leading him to look beneath official explanations of events to unmask shady and disturbing truths about state complicity. Yet, in each case, the viewer's alignment with this protagonist is ambiguous.

This point can be illustrated on a relatively obvious level by the opening sequence of Silent Action, in which a series of captions frame the deaths of senior army personnel. The circumstances around each death are depicted in detail, to either suggest or explicitly reveal that we are witnessing a murder rather than an accident or a suicide. Each death is immediately followed by an explanatory headline superimposed over a whirring printing press, and in each case the headline's inadequacy or inaccuracy creates an epistemological dissonance between what the viewer has just witnessed and what public explanation is being presented. The spectacular car crash on a Milanese autostrada is preceded by close-up shots inside the vehicle, of Major Lorusso suddenly realizing that his brakes are malfunctioning: a clearly suspicious death that is explained as a 'frightening incident' in the accompanying headline. The demise of Colonel Scanni is even more explicitly shown to be the work of criminals, who knock him unconscious and force him to take his own life. Unsurprisingly, the headline announces an 'unexplained suicide'. Finally, the death of General Stocchi is described as 'mysterious', but the accompanying question 'crime or suicide?' has already been answered for the viewer, who has seen the unconscious General's body being carefully placed on a train track. The full significance of these deaths will only unravel to the viewer as the planned military coup is divulged through the course of the film, but the premise that murderous intrigue is afoot, and remains hidden from public knowledge, is a given from the start. The film's hero Commissario Solmi then enters the narrative in a state of ignorance and incrementally comes to discover the truth, placing the audience at a remove from him: one step ahead, and waiting for him to catch up.

With reference to Silent Action, Alan O'Leary argues that the poliziottesco's conspiracy mode was, for Italians consuming these films amid the turmoil of the era, performing a ritual function, whereby the hero witnesses the criminality and degradation of the contemporary Italian city on behalf of the spectator [and assumes] the vain burden of struggle against it' (2011: 100). Thus, for O'Leary, the hero operates as 'a scapegoat and fantasy representative who assuages or avenges the spectator's sense of social and economic insecurity or political impotence' (2011: 103). If we develop this argument into an appraisal of the narrative strategies deployed in these films, the identification of a ritual function further illuminates the 'revelatory' insight on offer to the spectator: one akin to Aristotle's concept of anagnorisis ( [c.335 BC] 2008: 19-21). This word, referring to a change from ignorance to awareness, is usually translated from the Greek as either 'discovery' or 'recognition'. Northrop Frye outlines how the latter usage denotes dramatic plots in which the moment of revelation is a shock for the central character, but not for the audience, who have known what is coming all along (Frye et al. 1985: 353). In its original (ancient) mythological context, this meaning of anagnorisis does not refer solely to audience knowledge obtained from what the plot has shown up to that point in 
7. I use this word (which commonly denotes a peculiarly 'Italian' refusal to believe official explanations), not to make any grand claims about Italian audiences' actual outlooks, but to identify the assumptions made about their attitudes by the film-makers under consideration.

8. A careful listener will identify the character's voice as that of the Interior Minister encountered earlier in the film, but the scene's construction wilfully obscures this realization. the diegesis, but to a broader cultural awareness of, and familiarity with, the dramatic ritual being enacted onstage. Such a model seems apt to explain the 'revelatory' performance of conspiracy on show in the films considered in this article: the unmasking of culpability operating as a ritual recognition of always-already accepted political tenets.

To appraise this point, it is necessary to move beyond analysis of such narrative devices as the dramatic irony outlined above in the case of Silent Action, and consider the extent to which the viewer's level of cultural recognition is presupposed to be already in a privileged position over the commissario hero. Approaching these films on their own terms, as it were, we can see them functioning, not to 'explain', investigate or illuminate the finer details of the intrigue and its culpabilities, but instead to use an already pervasive corruption as a backdrop, stage and forum for an unfocused but assumed dietrologia ${ }^{7}$ that does not require sophisticated analysis or articulation. The ending of Execution Squad, even while it unmasks former chief of police Stolfi as complicit in the intrigue, ultimately obfuscates the precise culpabilities for the coup conspiracy. The denouement makes it clear that Bertone's suspicions of an elite cabal seeking to manipulate public opinion and overthrow the democratic order were correct. Stolfi's calm declaration that nobody will find out about the murder of Bertone or the larger plot because he knows how to manipulate the media, while putting a seal on the film's broader accusations that mainstream outlets of public information were complicit in the cover-ups that accompanied stragismo, should also be seen as a self-reflexive gambit. The film's viewer, of course, does know of the conspiracy, having just heard Bertone and Stolfi talking at length of its mechanisms and then having witnessed its dastardly ruthlessness in the revelatory act of betrayal. As District Attorney Ricciuti vows to continue Bertone's investigation, however, he is challenged by a man who is clearly a high-ranking official, but whose precise identity is hidden from the viewer thanks to conspicuous mise-en-scène that conceals his face behind a car door frame as the film draws to an end. ${ }^{8}$ The implicit suggestion appears to be that a level of complicity, to which the viewer is finally not party, exists above Stolfi. Far from offering lucid analysis or explanation, the outlook that emerges here is one of certainty that highlevel intrigue is afoot, coupled with a literal inability conclusively to unmask its agents or to pin down its precise nature.

The persistence of neo-fascist anonymity on display here adheres to a broader pattern in Italian cinema of the era identified by Alfeo Leotta, whereby right-wing radicals are depicted as 'monodimensional characters, mysterious or sometimes invisible hit men who do not display any emotion and are dangerously ubiquitous' (2013: 149). In the case of the polizottesco's treatment of conspiracy, this tentative representation of neo-fascism is also tangible in the films' omissions and oversimplifications. Violent Professionals, for example, presents its protagonist with a convoluted riddle that does very little to clarify the political situation, whereby a hippie commune (decorated in CND symbols and 'flower-power' iconography) is implicated in the web of intrigue that leads his investigations through a politically motivated assassination, an organized crime boss and his gang of hoodlums, their professed determination to spread chaos and influence public opinion, and the ultimate revelation that the police chief is the puppet master of all the turmoil. This unmasking of the hero's erstwhile ally should firstly be recognized as an opportunistic and familiar filone echo of Execution Squad, whose box-office success had pointed to the lucrative potential of such repetition the year before. Second, the crime
1.

2.

3.

4.

5.

6.

7.

8.

9.

10.

11.

12.

13.

14.

15.

16.

17.

18.

19.

20.

21.

22.

23.

24.

25.

26.

27.

28.

29.

30.

31.

32.

33.

34.

35.

36.

37.

38.

39.

40.

41.

42.

43.

44.

45.

46.

47.

48.

49.

50.

51.

52. 
network and political motivations depicted in this film do not in any way render the era's confusions coherent. On the contrary, they make these confusions manifest, by unproblematically conflating leftist agitation with a rightwing strategy of tension in a reductive framing of 'political violence' per se.

My point is not to denigrate these film-makers' understanding of political or historical processes. Rather, it is to argue that Execution Squad, Violent Professionals and the subset of the poliziottesco of which they are part, take corruption and conspiracy as an accepted starting point and therefore offer little pretence towards complex analysis or investigation into its precise political motivations on behalf of their viewers. To approach these films trying to find such insight, or to be disappointed when we fail to do so, would be to overlook the cultural and political coordinates of the poliziottesco's industrial milieu. These films' progression towards their 'revelatory' unmasking of official culpability instead offers something akin to what Christopher Wagstaff describes as filone cinema's 'pay-off' (1992: 253): an anticipated thrill or gratification whose repetition characterizes a given formula or strand. Once the archetype is established in Execution Squad, the ritual performance of the hero's revelation and the 'confession' of a high-powered ringleader explicitly asserting the need to foment chaos in society to alter pubic opinion and topple the democratic status quo offer such gratification, as a formulaic ending repeated in each of the films discussed here. Though each film positions this act of 'unmasking' as its pivotal moment, the revelation on offer is less an epistemological one of being told that arms of the state might act as covert sponsors for terror, and more a cathartic one of witnessing an incremental variation on a filone trope: the hero eliminating the ringleader (Violent Professionals, The Great Kidnapping, The Big Racket), perishing in his heroic attempt to do so (Execution Squad, Silent Action), or both (Crimebusters).

\section{CONCLUSION}

There are, of course, omissions in my analysis. I have argued that Execution Squad is to some extent a document of its era's uncertainties, that it performed a ritual recognition rather than a precise unmasking of pervasive corruption, and that it initiated a particular strand of filone cinema that continued in this discursive vein through the following years. It goes without saying, however, that these films did not exist in a cinematic vacuum. Indagine su un cittadino al di sopra di ogni sospetto/Investigation of a Citizen Above Suspicion (Petri, 1970), for example, examines the hard-wired eagerness of the authorities to overlook evidence pointing to high-level culpability for violence, and preceded Steno's film. In turn, Cadaveri eccellenti/Illustrious Corpses (Rosi, 1976) has been analysed for its indebtedness to this cycle of poliziotteschi (O'Leary 2011: 83-91). Io ho pauralI Am Afraid (Damiani, 1977), too, has a close affinity to this variant of the poliziottesco through its plot of a policeman uncovering links between a terrorist attack and a planned secret service coup. Each of these films can loosely be placed in a 'police procedural' generic framework, and each therefore provides a valuable case study to appraise the cultural-political outlooks inherited and then negotiated by this filone. As has been studied elsewhere, however, each also offers a more sophisticated analysis of the era's cover-ups, by offering varying degrees of philosophical examination into the distinction between left- and right-wing terror, as well as the authorities' efforts to frame leftist extremists. ${ }^{9}$ No such detail exists in the poliziotteschi under consideration here, in which 'public opinion' is repeatedly presented by
9. See especially O'Leary (2011: 83-91) and

Wood (2013: 33-38) For example, Wood identifies in both Investigation of a Citizen above Suspicion and Illustrious

Corpses a thematic analysis of ideology and power coercing and indoctrinating the populace into acceptance of the state's operations (2013: 36-37). 
10. For example, see Gunning's (1990) analysis of the 'cinema of attractions'

11. With this conclusion, I am developing an argument I previously put forward in The Italianist (Fisher 2013) the plotters as a self-explanatory entity to be straightforwardly manipulated by spreading violence. My concern here has been with how this specific filone variant documents this political register: one of innate suspicion and assumed distrust, rather than lucid analysis or psychological depth.

The arguments I have pursued here are not very far removed from longestablished film studies debates surrounding the importance of causality, motivation and goal-orientation in narrative cinema. Numerous scholars have questioned the premise that an audience's desire for causal coherence or realism are the fundamental axes of film's appeal, and examined instead the extent to which emotional affect and moments of spectacle might have been just as, if not more, decisive factors in the success of the medium from the late nineteenth century onwards. ${ }^{10}$ Italian film scholarship too (commonly, as here, following Wagstaff 1992) increasingly explores the specific conditions of production and consumption that characterized filone cinema, in which fragmented spectacle and emotional release would supersede cogent narrative development. As we have seen, however (and notwithstanding the valuable recent interventions of Marlow-Mann (2013) and O'Leary (2011)), where popular cinema's relationship to the anni di piombo is concerned, arguments positing that the medium's role was to make sense of the era's events persist.

Returning to my earlier argument that the events of the 1970s were inseparable from the processes of mediation that grew around them, we can place the poliziottesco's conspiracy mode within the spectrum of discursive construction that would become Italy's 'anni di piombo'. To assume that narrative integrity is the primary function of these films is to shoehorn them into a illfitting mode of political address in this era, when their ritual performance of conspiracy, their filone production values, their oversimplifications and their investment in spectacle are in fact integral to their immediacy. They are, finally, illuminating historical documents: not of incisive critique, investigative rigour or intellectual insight, but of one available political register, through with the events were being represented to sections of the Italian public. By incorporating familiar transatlantic schemas into equally familiar and assumed conspiracy modes, they chronicle a fragmentary, rapidly changing cultural-political landscape. The phrase 'political cinema' is often used to denote 'commitment' or to bolster the cultural capital of a film, but it should also be considered for its ability to document the cultural options open to its intended audiences: in this case audiences for whom both sensationalized representations of the anni di piombo and the accoutrements of US popular culture were becoming ever more familiar mediators. ${ }^{11}$

\section{REFERENCES}

Anon (1970), La strage di stato: controinchesta/The State Massacre: CounterInquiry, Rome: Samonà e Savelli.

Aristotle ([c. 335 BC] 2008), Poetics, New York: Cosimo Classics.

Barry, Christopher (2004), 'Violent justice: Italian crime/cop films of the 1970s', in Ernest Mathijs and Xavier Mendik (eds), Alternative Europe: Eurotrash and Exploitation Cinema Since 1945, London: Wallflower, pp. 77-89.

Bellocchio, Marco (1972), Sbatti il mostro in prima pagina/Slap the Monster on Page One, Rome: Jupiter Generale Cinematografica.

Bondanella, Peter (2009), A History of Italian Cinema, London: Continuum. Bordwell, David and Thompson, Kristin (2010), Film Art: an Introduction, New York: McGraw-Hill.
1.

2.

3.

4.

5.

6.

7.

8.

9.

10.

11.

12.

13.

14.

15.

16.

17.

18.

19.

20.

21.

22.

23.

24.

25.

26.

27.

28.

29.

30.

31.

32.

33.

34.

35.

36.

37.

38.

39.

40.

41.

42.

43.

44.

45.

46.

47.

48.

49.

50.

51.

52. 
Castellari, Enzo G. (1976), Il grande racket/The Big Racket, Rome: Cinemaster S.r.1.

Cento Bull, Anna (2007), Italian Neofascism: The Strategy of Tension and the Politics of Nonreconciliation, Oxford: Berghahn Books.

Cento Bull, Anna and Cooke, Philip (2013), Ending Terrorism in Italy, London: Routledge.

Curti, Roberto (2006), Italia Odia: il Cinema Poliziesco Italiano/Italy Hates: Italian Poliziesco Cinema, Turin: Lindau.

Damiani, Damiano (1977), Io ho pauralI Am Afraid, Rome: Auro Cinematografica.

De Maria, Renato (2009), La prima linea/The Front Line, Rome: Lucky Red.

Della Porta, Donatella (1995), Social Movements, Political Violence, and the State: A Comparative Analysis of Italy and Germany, Cambridge: Cambridge University Press.

Di Leo, Fernando (1972), La mala ordina/The Italian Connection, Rome: Cineproduzioni Daunia 70.

_ (1972), Milano calibro 9/Calibre 9, Rome: Cineproduzioni Daunia 70. (1973), Il boss/The Boss, Rome: Cineproduzioni Daunia 70.

Fisher, Austin (2013), 'Impegno, cultural capital and the politics of confusion', The Italianist, 33: 2, pp. 300-04.

Friedkin, William (1971), The French Connection, Los Angeles: D'Antoni Productions.

Frye, Northrop, Baker, Sheridan and Perkins, George (1985), The Harper Handbook to Literature, New York: Harper and Row.

Giordana, Marco Tullio (1995), Pasolini: un delitto italiano/Who Killed Pasolini?, Rome: Cecchi Gori Group Tiger Cinematografica.

Grindhouse Cinema Database (2012), 'Poliziotteschi', http://www.grindhousedatabase.com/index.php/Category:Poliziotteschi. Accessed 2 September 2013.

Gunning, Tom (1990), 'The cinema of attractions: Early film, its spectator and the avant-garde', in Thomas Elsaesser and Adam Barker (eds), Early Cinema: Space-Frame-Narrative, London: BFI, pp. 56-62.

Infascelli, Roberto (1973), La polizia sta a guardare/The Great Kidnapping, Rome: Primex Italiana.

Keighley, William (1935), G-Men, Los Angeles: Warner Bros.

Laviosa, Flavia (2013), 'Editorial', Journal of Italian Cinema \& Media Studies, 1: 1, pp. 3-6.

Leitch, Thomas (2002), Crime Films, Cambridge: Cambridge University Press.

Leotta, Alfio (2013), Nostalgics, thugs and psycho-killers: Neo-fascists in contemporary Italian cinema', Journal of Italian Cinema and Media Studies, 1: 2, pp. $143-56$.

Lumley, Robert (1990), States of Emergency: Cultures of Revolt in Italy from 1968 to 1978, London: Verso.

Marlow-Mann, Alex (2013), 'Strategies of tension: Towards a re-interpretation of The Big Racket and the Italian crime film', in Sergio Rigoletto and Louis Bayman (eds), Italian Popular Cinema, Basingstoke: Palgrave Macmillan, pp. $133-46$.

Martino, Sergio (1973), Milano trema - la polizia vuole giustizia/Violent Professionals, Rome: Dania Film.

— (1975), La polizia accusa: il servizio segreto uccide/Silent Action, Rome: Dania Film.

Moss, David (1989), The Politics of Left-Wing Violence in Italy, 1969-85, London: Macmillan. 
O'Leary, Alan (2011), Tragedia all'italiana: Italian Cinema and Italian Terrorisms, 1970-2010, Oxford: Peter Lang.

O'Rawe, Catherine (2011), "'A past that will not pass": Italian cinema and the return to the 1970s', New Cinemas: Journal of Contemporary Film, 9:2+3, pp. 101-13.

Petri, Elio (1970), Indagine su un cittadino al di sopra di ogni sospetto/Investigation of a Citizen Above Suspicion, Rome: Vera Films S.p.a.

Preminger, Otto (1950), Where the Sidewalk Ends, Los Angeles: Twentieth Century Fox Film Corporation.

Ray, Nicholas (1952), On Dangerous Ground, Los Angeles: RKO Radio Pictures.

Rosi, Francesco (1976), Cadaveri eccellenti/Illustrious Corpses, Rome: Produzioni Europee Associati (PEA).

Siegel, Don (1971), Dirty Harry, Los Angeles: The Malpaso Company/Warner Bros.

Steno (1972), La polizia ringrazia/Execution Squad, Rome: Primex Italiana.

Tarantini, Michele Massimo (1976), Poliziotti violenti/Crimebusters, Rome: Staff.

Tarrow, Sidney (1991), 'Violence and institutionalisation after the Italian protest cycle', in Raimondo Catanzaro (ed.), The Red Brigades and LeftWing Terrorism in Italy, London: Pinter Publishers, pp. 41-69.

Uva, Christian (ed.) (2007), Schermi di Piombo: Il Terrorismo nel Cinema Italiano/ Screens of Lead: Terrorism in Italian Cinema, Soveria Mannelli: Rubettino.

Uva, Christian and Picchi, Michele (2006), Destra e Sinistra nel Cinema Italiano: Film e Immaginario Politico dagli Anni '60 al Nuovo Millennio/Right and Left in Italian Cinema: Film and Political Imaginary from the 1960s to the New Millennium, Rome: Edizioni Interculturali.

Wagstaff, Christopher (1992), 'A forkful of westerns: Industry, audiences and the Italian western', in Richard Dyer and Ginette Vincendeau (eds), Popular European Cinema, London: Routledge, pp. 245-61.

Winner, Michael (1974), Death Wish, Los Angeles: Paramount Pictures.

Wood, Mary P. (2003), Revealing the hidden city: The cinematic conspiracy thriller of the '70s', The Italianist, 23: 1, pp. 150-51. (2012), 'Navigating the labyrinth: Cinematic investigations of rightwing terrorism', in Ruth Glynn, Giancarlo Lombardi and Alan O'Leary (eds), Terrorism Italian Style: The Representation of Terrorism and Political Violence in Contemporary Italian Cinema, London: IGRS Books, pp. 29-44.

Yates, Peter (1968), Bullitt, Los Angeles: Warner Brothers/Seven Arts.

Zinnemann, Fred (1952), High Noon, Los Angeles: Stanley Kramer Productions.

\section{SUGGESTED CITATION}

Fisher, A. (2014), 'Il braccio violento della legge: Revelation, conspiracy and the politics of violence in the poliziottesco', Journal of Italian Cinema $\mathcal{E}$ Media Studies 2: 2, pp. 167-181, doi: 10.1386/jicms.2.2.167_1

\section{CONTRIBUTOR DETAILS}

Austin Fisher is Senior Lecturer in Media Arts at the University of Bedfordshire, the editor of Spaghetti Westerns at the Crossroads (Edinburgh University Press, forthcoming) and the author of Radical Frontiers in the Spaghetti Western

1.

2.

3.

4.

5.

6.

7.

8.

9.

10.

11.

12.

13.

14.

15.

16.

17.

18.

19.

20.

21.

22.

23.

24.

25.

26.

27.

28.

29.

30.

31.

32.

33.

34.

35.

36.

37.

38.

39.

40.

41.

42.

43.

44.

45.

46.

47.

48.

49.

50.

51.

52. 
1. (IB Tauris, 2011). His main areas of expertise concern popular Italian cine2. ma's engagement with 1960s and 1970s countercultures. He serves on the 3. Editorial Board of the Transnational Cinemas journal, is Co-Chair of the SCMS 4. 'Transnational Cinemas' Scholarly Interest Group, and founder of the 5. Spaghetti Cinema festival in Luton, UK.

6. Contact: University Square, University of Bedfordshire, Luton LU1 3JU, UK.

7. E-mail: austin.fisher@beds.ac.uk

8.

Austin Fisher has asserted his right under the Copyright, Designs and Patents

11. Act, 1988, to be identified as the author of this work in the format that was submitted to Intellect Ltd.

13.

14.

15.

16.

17.

18.

19.

20.

21.

22.

23.

24.

25.

26.

27.

28.

29.

30.

31.

32.

33.

34.

35.

36.

37.

38.

39.

40.

41.

42.

43.

44.

45.

46.

47.

48.

49.

50.

51.

52. 